\title{
Atividades Organizadas de Lazer / Children's Organised Leisure Activities
}

https://doi.org/10.21814/uminho.ed.36.3

\section{Utsa Mukherjee}

Brunel University London, United Kingdom 



\section{Atividades Organizadas de Lazer}

O lazer das crianças, quando organizado, abrange uma gama de atividades "extracurriculares", que inclui desporto, aulas de expressões artísticas, acampamentos e escutismo, entre outras atividades que mantêm as crianças ocupadas fora da escola. Embora o catálogo de atividades organizadas de lazer para crianças esteja sempre a aumentar e varie de um lugar para outro, essas iniciativas partilham certas características. As atividades organizadas de lazer das crianças têm um caráter institucional, com horários e locais claramente definidos semanalmente. São atividades que acontecem em espaços supervisionados por adultos, onde as crianças precisam aderir a instrumentos fornecidos por adultos bem como, através delas, aprender múltiplas competências - ao mesmo tempo em que são rotulados como espaços de lazer e diversão. Mais importante ainda, a maioria dessas atividades - embora não todas - têm mensalidades que os pais devem pagar para que as suas crianças as possam frequentar.

As atividades organizadas de lazer são de particular interesse para a sociologia da infância porque revelam aspetos-chave dos padrões do uso do tempo pelas crianças e da sua geografia quotidiana. Ajudam a elucidar a lógica dos pais no processo educativo, o que muitas vezes os leva a matricular os filhos nessas aulas realizadas em tempo de lazer. Estudos empíricos nas últimas duas décadas identificaram uma mudança tangível no padrão do uso do tempo pelas crianças, no ritmo da vida familiar e na geografia quotidiana das crianças, especialmente na Europa e na América do Norte. Devido à crescente preocupação com riscos associados às brincadeiras ao ar livre não supervisionadas das crianças mais novas, houve uma redução nas brincadeiras livres e na mobilidade independente das crianças. Em vez delas, as atividades de lazer organizadas por adultos ganharam destaque. Há crianças com apenas três anos que estão matriculadas em diferentes conjuntos de atividades, com o objetivo de desenvolver competências interpessoais que podem utilizar noutros ambientes sociais, como a escola. As mensalidades, o volume de trabalho e tempo disponível dos pais, são fatores necessários para permitir a participação das crianças nessas atividades - uma clara divisão foi observada entre as crianças de classe média e as suas contrapartes pobres e da classe trabalhadora, no que diz respeito à participação no lazer organizado (ver Lareau, 2011; Vincent \& Ball, 2007). 
Os pais de classe média usam os recursos económicos para que os seus filhos participem em várias dessas atividades - e neste processo ajudam os seus filhos a conquistar ainda mais vantagens sociais, além da escolaridade. Com efeito, matricular os filhos em atividades fora da escola tornou-se uma pedra angular das práticas parentais intensivas, que são cada vez mais enquadradas como o padrão dominante da "boa parentalidade" nos tempos contemporâneos.

Como resultado, as famílias de classe média no Ocidente estão cada vez mais ocupadas à medida que os horários de atividades dos filhos regem o ritmo da vida. Padrões semelhantes também foram identificados entre as classes médias urbanas nos países em desenvolvimento, onde o lazer organizado das crianças passou a constituir um local-chave para a reprodução das vantagens sociais. Por outro lado, os pais da classe trabalhadora, muitas vezes, não têm os recursos necessários para sustentar as mensalidades das atividades de lazer dos filhos, o que é agravado ainda mais pela restrição de tempo imposta pelos seus horários rígidos de trabalho. A diferença de classe nos horários de atividades organizadas de lazer das crianças está, indiscutivelmente, a refletir-se em maiores vantagens sociais para as crianças de classe média.

As pesquisas sobre as atividades organizadas de lazer das crianças, até agora, concentraram-se principalmente na motivação dos pais, nos processos de classe social, nas mudanças estruturais nos padrões de uso do tempo das crianças e nos espaços quotidianos. No entanto, mais atenção precisa de ser dada ao desvendar do papel étnico-racial e de género neste campo, bem como também ao aproveitamento das próprias experiências e perspetivas das crianças (ver Friedman, 2013) quanto à participação neste tipo de atividades de lazer. Dados empíricos sobre o lazer organizado das crianças no Hemisfério Sul ou no Mundo Maioritário são escassos - e, portanto, há uma necessidade de estudos sistemáticos dessas questões para além das infâncias no Hemisfério Norte ou no Mundo Minoritário.

(Tradução de Marlene Schüssler D'Aroz)

\section{Children's Organised Leisure Activities}

Children's organised leisure encompasses a range of "extra-curricular" activities including sports, performing arts lessons, camps and scout activities that occupy children's outside-of-school time. Although the catalogue of organised leisure activities for children is ever increasing and varies from 
place to place - these activities share certain characteristics. Children's organised leisure activities have an institutional characteristic, with their set times and venues clearly demarcated in children's weekly schedules. These activities take place in adult-supervised spaces where children need to adhere to instructions given by adults and learn multiple skills - while at the same time these activities are branded as spaces for leisure and fun. Most importantly, the majority - although not all - of these activities come with subscription fees which parents need to pay for privately.

Organized leisure activities are of particular interest to the sociology of childhood because they reveal key aspects of children's time-use patterns and everyday situations, and clarify parental decisions that often drive children's enrolment into these leisure lessons (see Mukherjee, 2020). Empirical studies over the last two decades have identified a measurable shift in children's time-use pattern, the pace of family life and the everyday geographies of children's daily lives especially in Europe and North America. Owing to rising risk anxieties around younger children's unsupervised outdoor play, there has been a decline in children's free play and independent mobility. In its place, adult-organised leisure activities have become more prominent. Children, as young as three years, are being enrolled in different sets of activities which are equipping them with soft skills that they can then utilise in other social settings such as at school. Given the fees and the amount of parental work and time needed to enable children's participation in these activities, a clear divide has been noticed between middle-class children and their poor and working-class counterparts as far as organised leisure participation is concerned (see Lareau, 2011; Vincent \& Ball, 2007). Middle-class parents are using their class resources to send their children to multiple activities, in the process helping their children to garner even more social advantages beyond schooling. Indeed, enrolling children into outside-of-school activities has now become a cornerstone of intensive parenting practices which are increasingly being judged as the dominant yardstick of "good parenting". As a result, middle-class family lives in the West are increasingly becoming busier with children's activity schedules governing the pace of life. Similar patterns have also been discerned amongst the urban middle-classes in the developing world where children's organised leisure has come to constitute a key site for the reproduction of social advantages. On the other hand, working class parents often lack the resources needed to support children's leisure fees and this lack is further compounded by the time-constraint imposed by their rigid working hours. The class difference in children's leisure schedules is arguably translating into greater social advantages for middle-class children. 
The research on children's organised leisure activities has thus far focused primarily on parental motivation, social class processes, structural changes in children's time-use patterns and everyday spaces. However, more attention needs to be paid to the role of race, ethnicity and gender in this regard. Children's own experiences and perspectives (see Friedman, 2013) on leisure participation also need to be utilised. The empirical data on children's organised leisure in the Global South or the Majority world is rare, and therefore there is a need for a systematic exploration of these questions beyond the Global North or Minority world childhoods.

\section{Referências / References}

Friedman, H. L. (2013). Playing to Win: Raising Children in a Competitive Culture. Berkeley: University of California Press.

Lareau, A. (2011). Unequal Childhoods: Class, Race, and Family Life (2nd ed.). Berkeley: University of California Press.

Mukherjee, U. (2020). Towards a critical sociology of children's leisure. International Journal of the Sociology of Leisure, 3(3). doi: 10.1007/s41978-020-00060-5

Vincent, C. \& Ball, S. J. (2007). Making Up' the Middle-Class Child: Families, Activities and Class Dispositions. Sociology, 41(6), 1061-1077. doi: 10.1177/0038038507082315 